\title{
SINGLE NUCLEOTIDE POLYMORPHISMS OF LIPOPROTEIN LIPASE GENE AND ITS ASSOCIATION WITH MARBLING QUALITY IN LOCAL SHEEPS
}

\author{
Hidayati ${ }^{*}$, C. Sumantri, R. R. Noor, R. Priyanto and S. Rahayu \\ Faculty of Animal Science, Bogor Agricultural University, \\ Jl. Agatis, Darmaga Campus, Bogor 16680 - Indonesia \\ * Permanent address: Breeding and Genetic Laboratory, Faculty of Agricultural and Animal Science, \\ State Islamic University of Sultan Syarif Kasim - Riau, \\ Kampus II Raja Ali Haji, Jl. HR. Soebrantas KM 15 Panam, Pekanbaru 28293 - Indonesia \\ Corresponding E-mail: yati_suska@yahoo.com
}

Received November 27, 2014; Accepted January 13, 2015

\begin{abstract}
ABSTRAK
Lipoprotein lipase (LPL) merupakan enzim kunci dalam metabolisme dan transport lipoprotein yang mempengaruhi level trigliserida darah. LPL mengontrol partisi triasilgliserol antara jaringan lemak dan otot serta dapat meningkatkan penyimpanan lemak atau menyediakan energi dalam bentuk asam lemak untuk pertumbuhan otot. Penelitian ini bertujuan untuk mengeksplorasi keragaman gen LPL pada domba lokal Indonesia dan hubungannya dengan kualitas marbling. Total 66 DNA genom (260 bp) domba lokal Indonesia yang terdiri atas domba ekor tipis sumatera (50 ekor) dan domba garut (16 ekor) digunakan dalam penelitian ini. Amplifikasi DNA genome menggunakan Polymerase Chain Reaction dan metode direct sequencing digunakan untuk mengidentifikasi keragaman sekuens. Hasil sekuens dianalisis menggunakan software Bioedit dan MEGA 5.2. Sekuens kemudian disejajarkan menggunakan metode Clustal W dengan gen bank X.68308.1. Assosiasi keragaman gen LPL dengan kualitas marbling dianalisis menggunakan metode ANOVA satu arah dan uji lanjut menggunakan uji beda nyata terkecil. Hasil penelitian menemukan 3 SNPs baru pada posisi basa g.26>C/G, g.27>G dan c.192 $\mathrm{T}>\mathrm{C}$ pada domba garut dan insersi g.26>C/G pada domba ekor tipis sumatera. Keragaman gen LPL posisi basa c.192 pada domba garut berasosiasi dengan asam lemak heneikosanoat, dimana genotipe TT $(0.04 \%)$ memiliki kandungan lebih tinggi dibandingkan genotipe CC $(0,03 \%)$ dan CT $(0,02 \%)$.

Kata kunci: gen LPL, SNPs, lamb, asam-asam lemak, henekosanoat
\end{abstract}

\begin{abstract}
Lipoprotein lipase (LPL) is a key enzyme that plays in metabolism and transport lipoprotein and therefore has an influence on blood triglyceride levels. LPL controls triacylglycerol partitioning between adipose tissue and muscle that increases fat storage or provides energy in the form of fatty acids for muscle growth. The research was aimed to explore Single Nucleotide Polymorphisms of LPL gene and to associate SNP with marbling quality. A total of 66 genomic DNAs consisted of sumatera thin-tail ed sheep (50 heads) and garut sheep (16 heads) were used in this study. Polymerase Chain Reaction was used to amplify genomic DNA and direct sequencing method was to identify polymorphism sequences. The sequences were analyzed with Bio Edit and MEGA 5.2. The BLAST sequence was obtained from gene bank X.68308.1. The association between the genotype and marbling quality was analyze by one way ANOVA and further between mean differences were tested using least sgnificant difference. The results showed that 3 novel SNPs i.e. insertion g.26>C; insertion g.27> G and c.192T $>C$ on garut sheep and a SNP insertion g.26 $>\mathrm{C} / \mathrm{G}$ on sumatera thin-tail ed sheep. The diversity of LPL gene at c.192T $>\mathrm{C}$ was associated with heneicosanoic acid, whereas TT genotype $(0.04 \%)$ was higher than $\mathrm{CC}(0.03 \%)$ and CT $(0.02 \%)$.
\end{abstract}

Keywords: LPL gene, SNPs, lamb, fatty acids, heneicosanoic acid 


\section{INTRODUCTION}

Meat quality can be defined as factors that affect consumers' assessment of the quality of the meat where the meat quality is associated with polygenic traits (Dunner et al., 2013). The consumer's decision of cooked meats including tenderness, juiciness and flavor, is closely associated with marbling quality (Hocquette et al., 2006). Marbling or intramuscular fat is the flecks and streaks of fat within the lean sections of meat (Guo et al., 2014).

Depositions of animal body fat were found in the visceral, subcutan, intermuscular and intramuscular. Distribution of fat, fatty acid composition and type of muscle fibers, approximately $35 \%$ were influenced by genetic (Williams, 2008) and varieties of environmental factors. Marbling affect consumers' assessment because these fats cannot be separated from the meat, the fat is different from the other parts.

Fats composed of glycerol esters, cholesterol, phospholipids and fatty acids. Fatty acids are grouped into 3 categories: saturated fatty acid (SFA), mono unsaturated fatty acid (MUFA) and poly unsaturated fatty acid (PUFA). Nutritional guidelines suggest that fat intake ranged from $15 \%-30 \%$ of total caloric needs, SFA is limited between $0-10 \%$, MUFA 16\%, PUFA 7\% and cholesterol should not exceed $300 \mathrm{mg} /$ day (Wong, 1989; Chizzolini et al., 1999). SFA consumption that exceeded the needs is suspected as the cause of various diseases such as cardiovascular disease, atherosclerosis and other diseases. Heritability of fatty acid composition of scottish blackface sheep marbling was ranged from moderate to high (Karamichou et al., 2006), which indicates a large genetic influence.

Selection of marbling quality using conventional methods, difficult and expensive relatively, so based on phenotype selection, marbling quality rarely included. Alternative that can be done is through genomic selection. Genomic selection begins with the discovery of candidate genes were associated with desirable traits. One is through the exploration of single nucleotide polymorphisms (SNPs) of the gene and then associated with the desirable traits. SNPs are DNA sequence variations that when arise a single nucleotide (A, T, C or $\mathrm{G}$ ) is different from the sequence generally. The among the genes influence marbling quality was LPL gene. Sevane et al. (2013) reported that LPL gene diversity in some breeds of cattle was associated with increased fatty acid gamma-linolenic acid and dihomo-arachidonic fatty acids.

Lipoprotein lipase (LPL) is a major enzyme that plays in metabolism and transport lipoprotein and therefore it has an influence on blood triglyceride levels (Wang \& Eckel, 2009; Crissa et al., 2010; Holmes et al., 2011). Lipoprotein components comprise of cholesterol, triglycerides, phospholipid and apolipoprotein. Triglycerdes in VLDL are hydrolyzed by LPL in the blood capillaries. LPL controls triacylglycerol partitioning between adipose tissue and muscle that increases fat storage or provides energy in the form of fatty acids for muscle growth (Bonnet et al., 2000; Ren et al., 2002; Dunner et al., 2013).

LPL is produced in adipose tissue, heart and skeletal muscle and then transferred to the surface of capillary endothelium. LPL was encoded by the LPL gene consist of 10 exons and 9 introns which were located on chromosome 2 in Ovis aries (www.animalgenome.org/cgi-bin/QTLdb/OA).

LPL gene polymorphisms and its associations with marbling quality has no such studies were conducted in Indonesian local sheep. The objectives of this study were to explore SNPs of LPL gene in the coding region and its association with lamb marbling quality of local sheep.

\section{MATERIALS AND METHODS}

\section{Materials}

Blood samples from 50 heads sumatera thin tail ed sheep (Padang, West Sumatera) and 16 heads garut sheep (Garut, West Java) were collected by using venoject $2-3 \mathrm{~mL}$ from jugular vein. The blood samples were preserved in ethanol absolute $96 \%$ with ratio of $1: 1$ and kept in room temperature for laboratory analysis. The intramuscular fat samples were collected from $m$. longissimus dorsi of Garut sheeps to analyze fat, cholesterol and fatty acid composition.

\section{DNA Extraction and Amplification Using PCR Method}

Genomic DNA was extracted by using Phenol-chloroform technique (Sambrook et al. 1989) and modified by using buffer lysis cell (250 $\mu \mathrm{L} 1 \times \mathrm{STE}, 40 \mu \mathrm{L}$ SDS and $10 \mu \mathrm{L}$ proteinase-K). The DNA was purified by adding $40 \mu \mathrm{L} 5 \mathrm{M}$ $\mathrm{NaCl}, 400 \mu \mathrm{L}$ phenol chloroform and $400 \mu \mathrm{L}$ CIAA (Chloroform Iso Amyl Alcohol) and precipitated by using $40 \mu \mathrm{L} 5 \mathrm{M} \mathrm{NaCl}$ and $800 \mu \mathrm{L}$ ethanol absolute. The precipitation was washed 
once by adding $800 \mu \mathrm{L}$ of $70 \%$ ethanol and centrifuged with the speed of $12.000 \mathrm{rpm}$ for 5 minutes. The ethanol was discarded and evaporated, than the precipitated DNA was disolved in $100 \mu \mathrm{L}$ of $80 \%$ TE (Elution buffer).

Polymerase chain reaction (PCR) method was used to amplify the fragment of LPL gene. The primers used were designed using the Primer Blast program from NCBI (http://www.ncbi. nlm.nih.gov/ tools.primer-blast) with reference to GenBank accession number X.68308.1. The forward primer sequence was F'5AAACCTGCCGCTTCTAGCTC-3' and reverse primer sequence was F'5TCTTGTAATCCTGTCGGCGG -3'. The primer sequences flanking the base position at 17 to 277 with a length of $260 \mathrm{bp}$ sequence was a small part of the 5'UTR and the first exon of LPL gene (Figure 1).

Each PCR reaction was made with cocktail $50 \mathrm{ng}(2-3 \mu \mathrm{L})$ DNA template, $0.25 \mu \mathrm{M}$ primer forward and reverse, $12.5 \mu \mathrm{L}$ Dream Tag Green Master Mix from Thermo Scientific \#K 1081 and $\mathrm{dH}_{2} \mathrm{O}$ up to $25 \mu \mathrm{L}$. Samples were initially denaturated at $95^{\circ} \mathrm{C}$ for five minutes and followed by 35 cycles of denaturation at $95^{\circ} \mathrm{C}$ for $45 \mathrm{~s}$, annealing at $58^{\circ} \mathrm{C}$ for one min and extension at $72^{\circ} \mathrm{C}$ for one min. Final extension was at $72^{\circ} \mathrm{C}$ for 5 min. Gene Amp PCR system 9700 and Master Cycler Personal 22331 Eppendorf were used for PCR amplification. PCR products were then separated on $1.5 \%$ agarose $/ 0.5 \times \mathrm{TBE}$, stained with $2.5 \mu \mathrm{L}$ of ethidium bromide (EtBr) and calibrated with 100 bp ladder marker. Electrophoresis chamber was run on 100 volt power supply for thirty minutes. Finally, the gel was visualized under UV transilluminator (Figure 2). The PCR product samples were then subjected to direct sequence analysis by dideoxy sequencing in ABI $3730 \mathrm{XL}$ automated DNA sequencer at the $1^{\text {st }}$ base laboratory Singapore.

\section{Quality of Marbling Analysis}

Nine of sixteen of male garut sheeps, had aged 8-10 months and weight at slaughtered 22,46 $\mathrm{kg}$ was identified of diversity LPL gene at base c.192, consists of TT $(n=4)$, CT $(n=2)$ and CC $(\mathrm{n}=3)$, slaughtered and m.longissimus dorsi used to analyze lamb marbling quality. The fat determined with soxhlet method with petroleum eter (AOAC, 2005). The cholesterol content was carried out with dye $10 \mathrm{~g} \mathrm{FeCl}^{3} 6 \mathrm{H}^{2} \mathrm{O}$ in $100 \mathrm{~mL}$ glacial asetat acid (AOAC, 2005) by spectrometer in absorbance with wavelength of $565 \mathrm{~nm}$. The profile of fatty acids was followed AOAC (2005). The lipids after extraction were esterified and methylated with BF3 20\%. The methyl esters of fatty acids were separated and quantified in a gas chromatograph (GC-2010 plus Shimadzu).

\section{Data Analysis}

The results of sequences fragment of LPL were analyzed with BioEdit (Hall, 2011), MEGA version 5.2 (Kumar et al., 2004) and POP GENE ver.1.31 (Yeh et al., 1999) software. The BLAST sequence was obtained from Gene Bank with accession number of X.68308.1. The analyzed sequence was required to ensure the fragment of LPL gene of sheep and to find out the existence of mutation in LPL gene and polymorphisms in the sequences. Frequency of gene, genotype and Hardy-Weinberg equilibrium were estimated by Nei and Kumar (2000). The observed heterozygosity $\left(\mathrm{H}_{\mathrm{o}}\right)$ and excepted heterozygosity $\left(\mathrm{H}_{\mathrm{e}}\right)$ were estimated with POPGENE 32. The association between the genotype and marbing quality was analyze by one way ANOVA and Least Significant Difference (LSD) used to know different least squares means. The model mathematics is as follows:

$\mathrm{Y}_{\mathrm{ij}}=\mu+\mathrm{G}_{\mathrm{i}}+\mathrm{E}_{\mathrm{ij}}$

Where; $Y_{i j}$ is the traits measured in animal, $\mu$ is the population means, $G_{i}$ is the effect of genotype

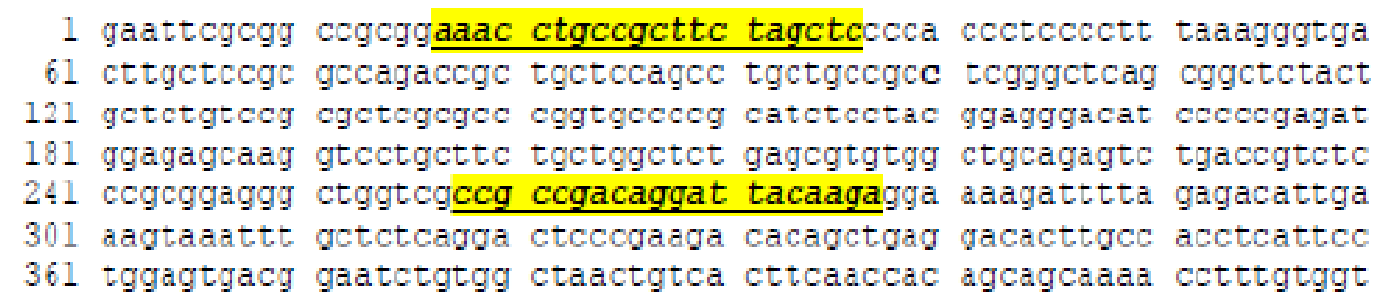

Figure 1. LPL Amplicon Sequence: Genbank X.68308.1. The primers sites were underlined and bold. 


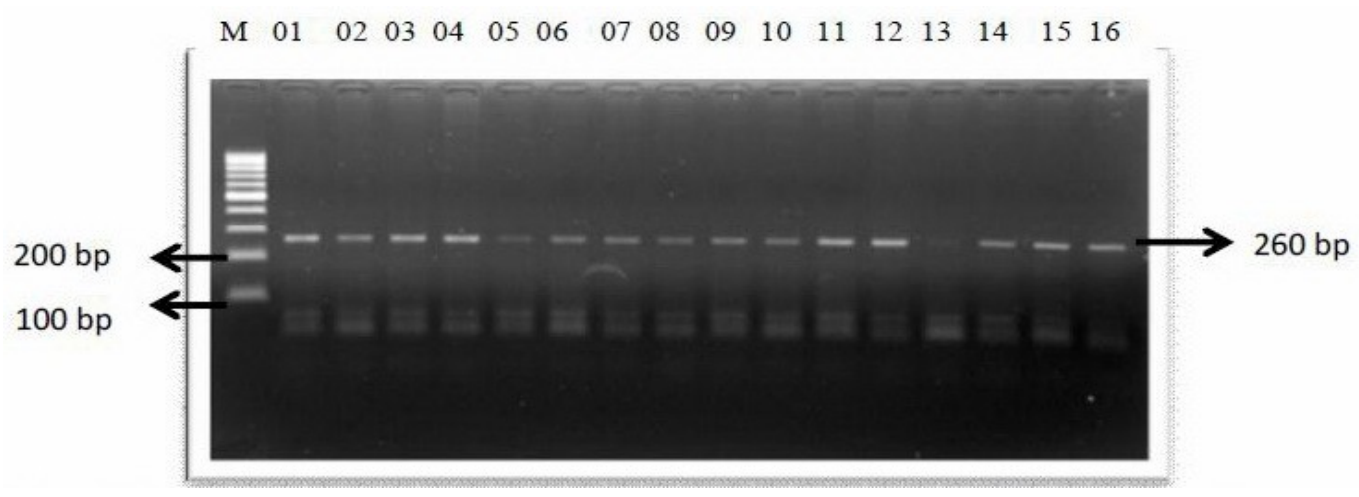

Figure 2. PCR Amplification of LPL Gene (260 bp); 0-16 = individual samples; $m=$ DNA ladder 100 bp.

and $\mathrm{E}_{\mathrm{ij}}$ the residual random effect associated with animal traits.

\section{RESULTS AND DISCUSSION}

\section{Single Nucleotide Polymorphisms of Lipoprotein Gene in Sumatera Thin Tailed and Garut Sheep}

Sixty six (66) sequences of sumatera thin-tail ed sheep (50) and garut sheep (16) on LPL gene encoding region were aligned with gene bank X.68308.1 (Figure 3). The results showed that one SNP i.e. insertion at base g. $26>\mathrm{G} / \mathrm{C}$ (Figure $4 \mathrm{~b}$ and Figure 4c). The one SNP was reconstructed three diplotypes: diplotype A, D and E (Tabel 1). Three SNPs were identified on Garut i.e. insertion at g. $26>\mathrm{C}$ and g. 27 $>\mathrm{G}$ (Figure 4a) and mutation at c.192T $>\mathrm{C}$ (Figure 5). These mutations were formed 5 diplotypes i.e. A, B, C, F and (Table 1). Diplotype A was similar to the gene bank sequences X.68308.1. Three novel SNPs in this study has never been reported in other sheep populations even though percentage of LPL gene diversity at base g.26 and g.27 were relatively low in both populations.

Insertion of at base position g.26>C and g.27 $>\mathrm{G}$ caused arise stop codon at amino acids at 13, 66 and 73 as was found on diplotype A, while insertion at base g.26> G/C, the stop codon arise of 6 and 15 of amino acids sequence (Figure 6). Mutation at base g.26 and g.26 were called frameshift mutation that is a mutation that causes a stop codon is not at place properly.

With regard to mutation at base c.192 on garut sheep, was identified substitution thymine to cytocine was non synonymous mutation, it changed amino acid (Val $>$ Ala) while in sumatera thin-tail ed sheep was monomorfic (Table 2). Frequency of $\mathrm{C}(0.59)$ was the predominant than $\mathrm{T}(0.41)$ in garut sheep. Frequencies of genotype were CC (0.44), CT (0.31) and TT (0.25) and this genotypes frequencies were in Hardy-Weinberg equilibrium $(\mathrm{P}>0.05)$ (Table 2).

Ding et al. (2011) reported that one SNP at exon 7 of LPL gene at base $19913 \mathrm{C}>\mathrm{T}$, which changed Phenylalanine $>$ Serine, responsible for carcass traits and lipid deposition in yak. Three SNPs found in 3'UTR of Lipoprotein Lipase gene g.74 T>C, g.130 T>C and g.133 T>A were associated with CLA content on milk sheep (Crissa et al., 2010) and other researchers have been no reports on the effect of these 3 SNPs.

\section{Association of Polymorphisms Lipoprotein Lipase Gene c. 192 with Marbling Quality of Garut Lamb}

As shown in Table 3 and Table 4, the polymorphisms of LPL gene at base c.192 T $>$ C did not significantly $(\mathrm{P}>0.05)$ was affected fat, cholesterol and fatty acid profiles at longissimus dorsi muscle, except on fatty acid profile of saturated fatty acid; one long chain saturated fatty acid heneicosanoic acid $(\mathrm{P}<0.05)$. Whereas, TT genotype $(0.04 \%)$ was higher than CT $(0.02 \%)$ and $\mathrm{CC}(0.03 \%)$. Heneicosanoic acid is a minor fatty acid in nature, but the presence of heneicosanoic (21:0) affect the meat quality. The presence of odd long-chain saturated fatty acids indicates accumulation of propionic acid and biotin deficiency. Propionate is one of the volatile fatty acids of rumen fermentation. Conversion propionate into methyl malonyl $\mathrm{CoA}$ requires biotin. The methyl malonyl CoA was required for elongated fatty acid process by providing two 


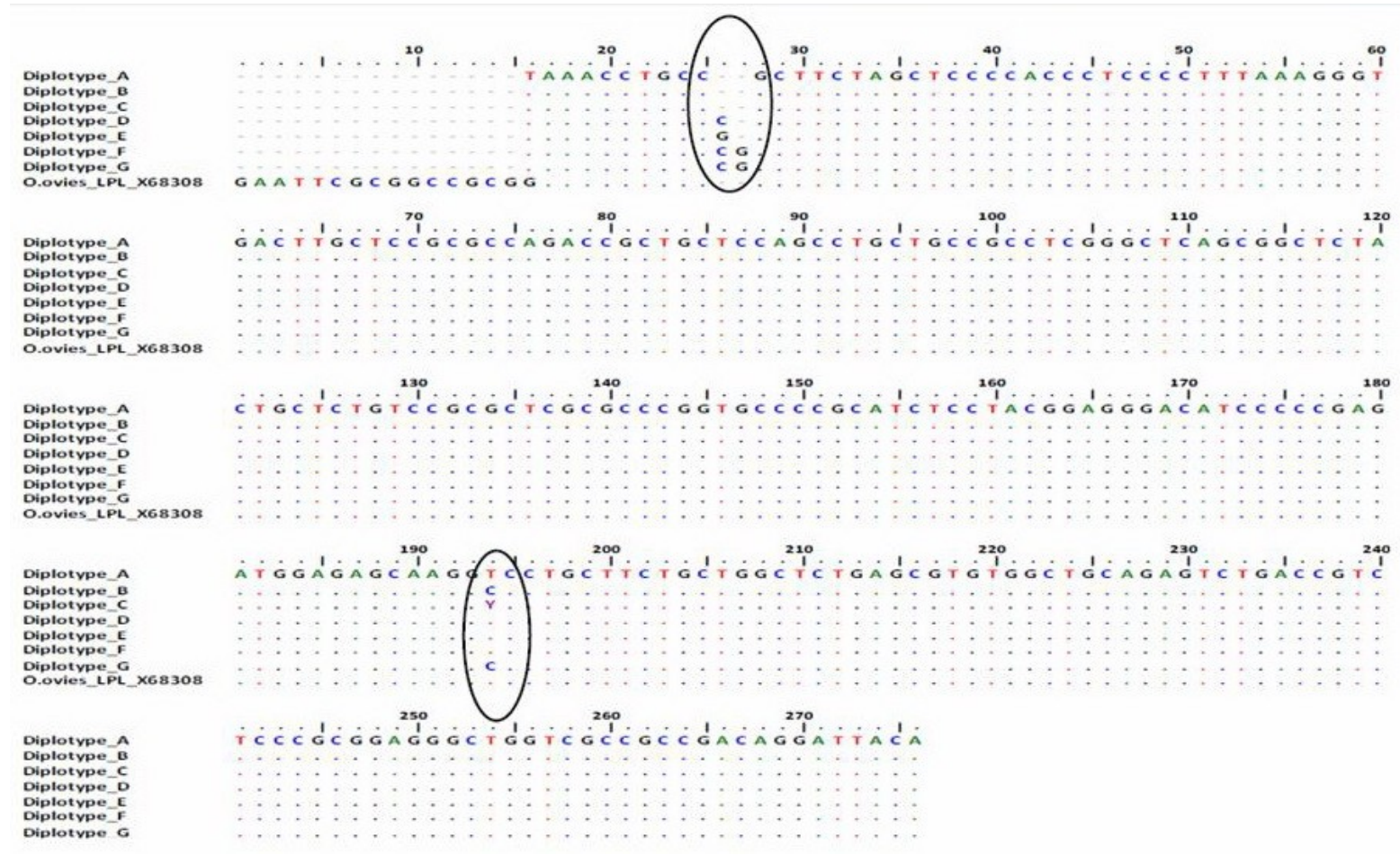

Figure 3. Alignmented of Lipoprotein Lipase Gene in Sumatera Thin-tailed Sheep and Garut Sheep

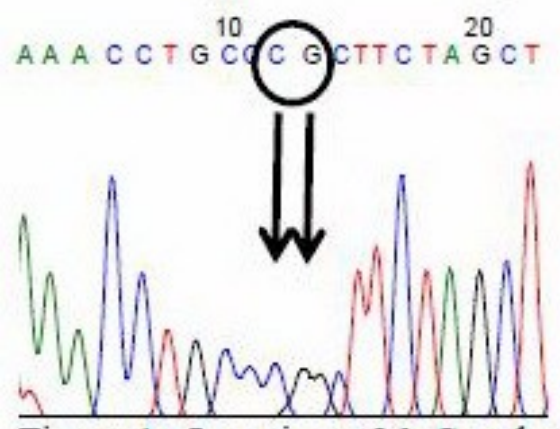

Figure 4a. Insertion g. $26>\mathrm{C}$ and g. $27>\mathrm{G}$

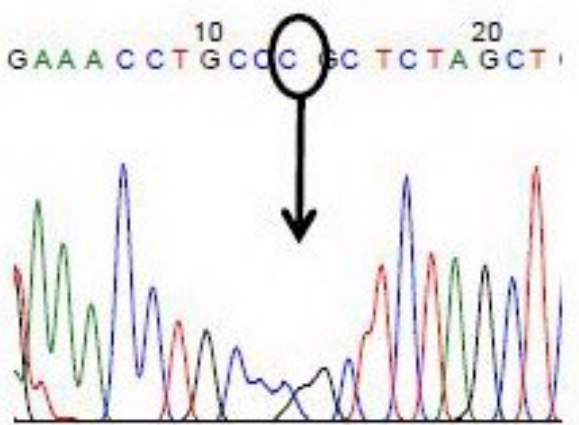

Figure $4 \mathrm{c}$. Insertion g. $26>\mathrm{C}$

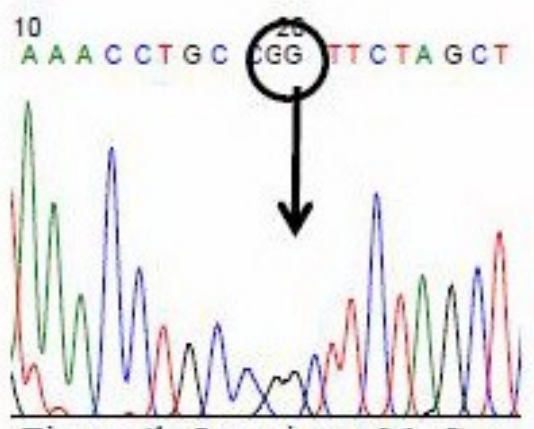

Figure 4 b. Insertion g. $26 \cdot \mathrm{G}$

A AACCTGC $\stackrel{10}{\mathrm{C}}$ GCTTCTAGCT

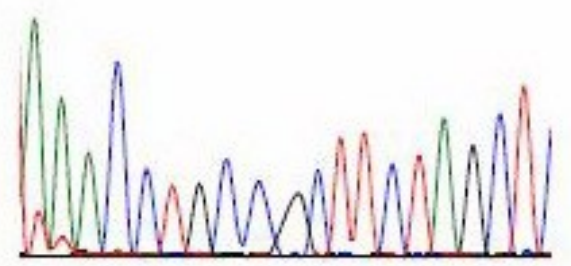

Figure $4 \mathrm{~d}$. No insertion g. 26 and g. 27

Figure 4. Partial Sequences of LPL Gene, which Showed Insertion at g. 26 and g.27 

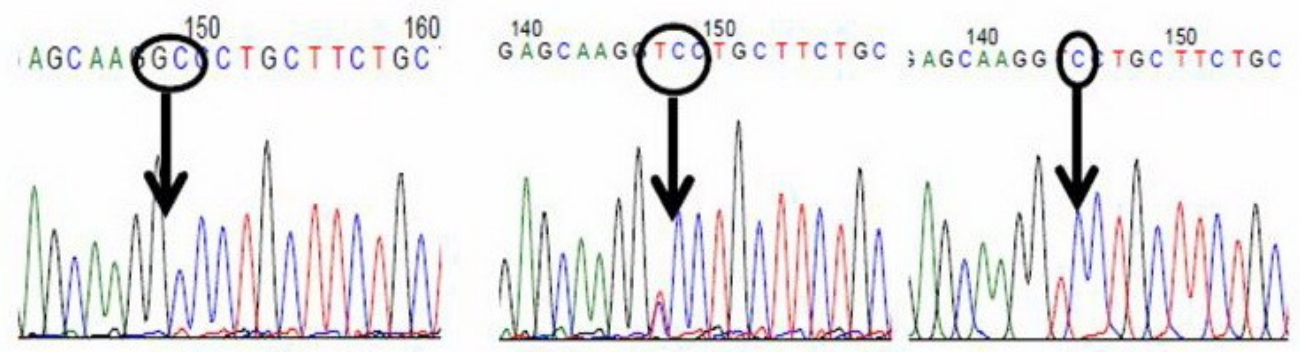

Figure 5. Partial Sequences of LPL Gene with a Mutation at Base c.192 T $>C$

Table 1. Diplotypes of LPL Gene of Sumatera Thin Tailed Sheep and Garut Sheep at Positions of 17 to 278 Bases

\begin{tabular}{|c|c|c|c|c|c|}
\hline \multirow{2}{*}{ Diplotype } & \multicolumn{3}{|c|}{ At mutation } & \multicolumn{2}{|c|}{ Frequency (n) } \\
\hline & c. 26 & g. 27 & c. 192 & STT & Garut \\
\hline Diplotype A & - & - & $\mathrm{T}$ & $0.840(42)$ & $0.1875(3)$ \\
\hline Diplotype B & - & - & $\mathrm{C}$ & $0.000(0)$ & $0.3750(6)$ \\
\hline Diplotype C & - & - & $\mathrm{C} / \mathrm{T}$ & $0.000(0)$ & $0.3125(5)$ \\
\hline Diplotype D & $\mathrm{C}$ & - & $\mathrm{T}$ & $0.020(1)$ & $0.0000(0)$ \\
\hline Diplotype E & $\mathrm{G}$ & - & $\mathrm{T}$ & $0.140(7)$ & $0.0000(0)$ \\
\hline Diplotype F & $\mathrm{C}$ & G & $\mathrm{T}$ & $0.000(0)$ & $0.0625(1)$ \\
\hline Diplotype G & $\mathrm{C}$ & G & $\mathrm{C}$ & $0.000(.0)$ & $0.0625(1)$ \\
\hline Total & & & & 50 & 16 \\
\hline
\end{tabular}

STT (Sumatera Thin Tailed sheep).
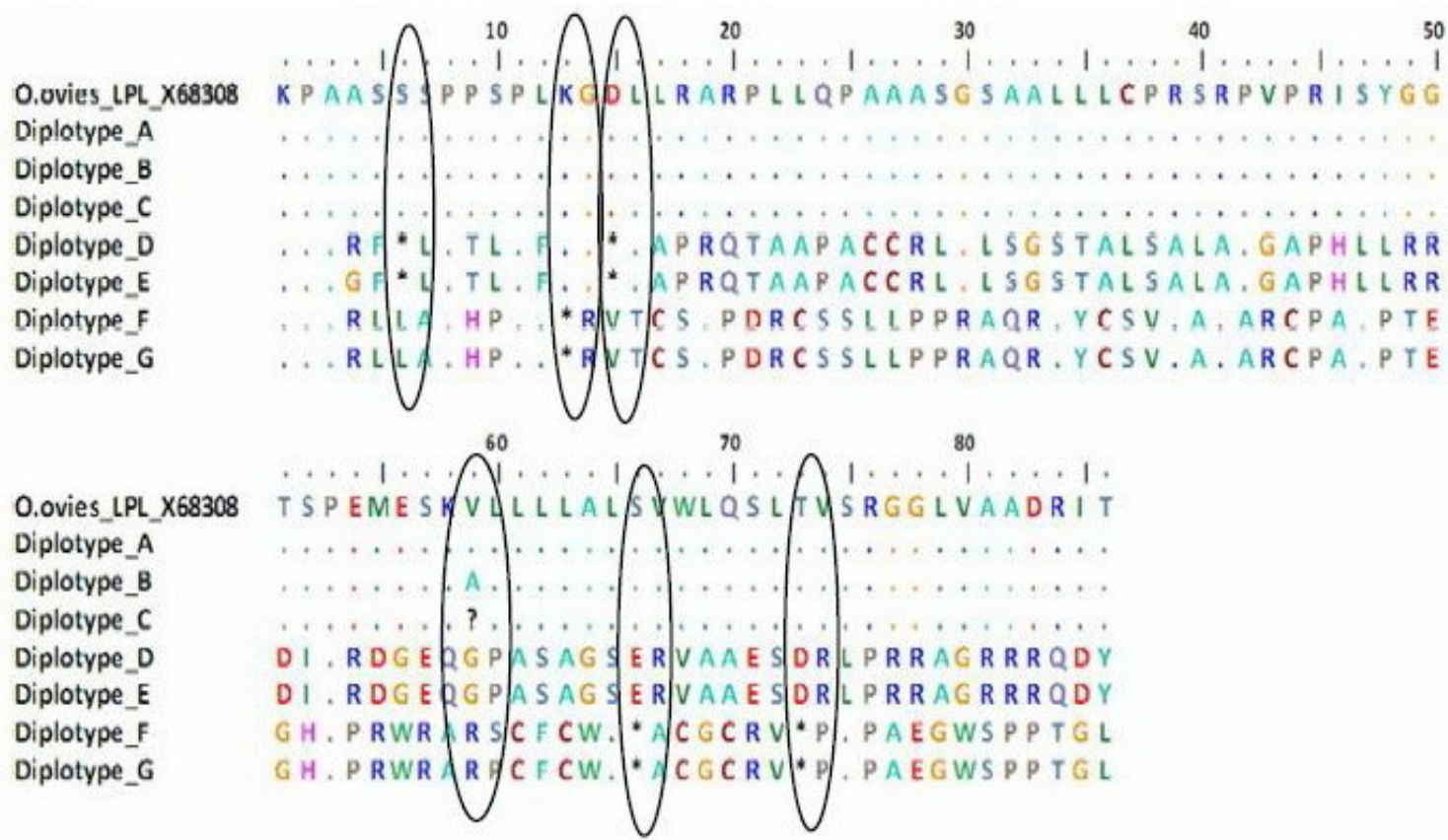

Figure 6. Alignmented of Amino Acids Sequences of Seven Dyplotypes of LPL Gene in Sumatera Thin Tailed and Garut Sheep 
carbon atoms. Biotin deficiency could inhibit the formation of methyl malonyl CoA and caused odd long-chain fatty acids. In addition, the presence of fatty acids heneicosanoic acid could oxidize omega fatty acids, but the exact mechanism is still unknown.

The results of this study indicate that the marbling fat content of garut sheep was $1.60 \%$ $-1.73 \%$, lower than other sheep breeds such as south african mutton, merino, dormer (Cloete et al., 2004), moranda nova, santa inez and crosses dorper x santa inez (Costa et al., 2009) as well as cholesterol content $(6.10 \%$ - 8.91\%) was lower than reported Costa et al. (2009) and Mas'ud (2012). It is suspected due to the age of the sheep were used relatively young (8-10 months), where the deposition of marbling not yet formed perfectly. Fat deposition was initially formed in the visceral, subcutaneous, intermuscular and last intramuscular. Cholesterol is a component of fat, while a little fat content, cholesterol content is also slightly.

LPL gene expression was influenced by nutrition, fat depot, adipocyte sizes, insulin levels, propionic acid levels (Ren et al., 2002; Lee and Hossner, 2002) and type of tissue where the gene was expressed (Sevane et al., 2013). The gene expression on marbling was lower than intermuscular, subcutaneous and perirenal. In the cattle, LPL was activated on muscles by peroxisome proliferator-activated receptor gamma (PPARG), when low glucose levels. PPARG previously activated by the sirtuin 1 (SIRT1) and peroxisome proliferator-activated receptor gamma coactivator 1 alpha (PPARGC1A). LPL leads to increased oxidation

Table 2. Frequency of Gene, Genotype, Heterozygosity and $\chi^{2}$ of Sumatera Thin Tailed Sheep and Garut Sheep at Base c. $192 \mathrm{~T}>\mathrm{C}$

\begin{tabular}{|c|c|c|c|c|c|c|c|c|c|}
\hline \multirow{2}{*}{ Population } & \multirow{2}{*}{$\mathrm{n}$} & \multicolumn{2}{|c|}{ Gene Frequency } & \multicolumn{3}{|c|}{ Genotype Frequency } & \multicolumn{2}{|c|}{ Heterozygosity } & \multirow{2}{*}{$\chi^{2}$ test } \\
\hline & & $\mathrm{C}$ & $\mathrm{T}$ & $\mathrm{CC}$ & $\mathrm{CT}$ & TT & Ho & $\mathrm{He}$ & \\
\hline Garut & 16 & 0.59 & 0.41 & 0.44 & 0.31 & 0.25 & 0.313 & 0.498 & $2.379^{\mathrm{ns}}$ \\
\hline STT & 50 & 0.00 & 1.00 & 0.00 & 0.00 & 1.00 & - & - & - \\
\hline
\end{tabular}

$\mathrm{STT}=$ Sumatera Thin Tailed sheep, $\mathrm{ns}=$ represent non significantly at $\mathrm{P}>0.05$

Table 3. Effect of Polymorphism of LPL Gene at Base c.192 on Fat, Cholesterol, SFA,MUFA, PUFA and Its Ratio of Lamb Marbling of Garut Sheep

\begin{tabular}{|c|c|c|c|c|c|c|c|}
\hline \multirow{3}{*}{ Variable } & \multicolumn{6}{|c|}{ Genotype } & \multirow{3}{*}{ Significance } \\
\hline & \multicolumn{2}{|c|}{$\mathrm{TT}(\mathrm{n}=4)$} & \multicolumn{2}{|c|}{$\mathrm{CC}(\mathrm{n}=2)$} & \multicolumn{2}{|c|}{$\mathrm{CC}(\mathrm{n}=3)$} & \\
\hline & Mean & $\mathrm{CV}$ & Mean & $\mathrm{CV}$ & Mean & $\mathrm{CV}$ & \\
\hline Fat (\%) & 1.730 & 0.68 & 1.680 & 0.21 & 1.600 & 0.56 & ns \\
\hline Cholesterol (\%) & 8.910 & 0.56 & 8.050 & 0.50 & 6.100 & 0.39 & ns \\
\hline SFA (\%) & 37.250 & 0.08 & 38.250 & 0.04 & 39.450 & 0.14 & ns \\
\hline MUFA (\%) & 26.410 & 0.09 & 30.650 & 0.16 & 29.780 & 0.21 & ns \\
\hline PUFA (\%) & 2.360 & 0.22 & 2.360 & 0.05 & 2.580 & 0.41 & ns \\
\hline MUFA/SFA ratio & 0.709 & 0.14 & 0.801 & 0.11 & 0.755 & 0.09 & ns \\
\hline PUFA/SFA ratio & 0.063 & 0.30 & 0.062 & 0.01 & 0.065 & 0.55 & ns \\
\hline
\end{tabular}

SFA = Saturated Fatty Acid; MUFA = Mono Unsaturated Ffatty Acid; PUFA = Poly Unsaturated Fatty Acid; $\mathrm{CV}=$ Coefficient of Variance; $\mathrm{n}=$ sample size 
Table 4. Association of Diversity of LPL Gene at Base c.192 with Fatty Acid Profile of Lamb Marbling of Garut Sheep $(\% \mathrm{w} / \mathrm{w})$

\begin{tabular}{|c|c|c|c|c|c|c|c|c|}
\hline \multirow{3}{*}{ Fatty Acids } & & \multicolumn{6}{|c|}{ Genotype } & \multirow{3}{*}{ Sig } \\
\hline & & \multicolumn{2}{|c|}{$\mathrm{TT}(\mathrm{n}=4)$} & \multicolumn{2}{|c|}{$\mathrm{CT}(\mathrm{n}=2)$} & \multicolumn{2}{|c|}{$\mathrm{CC}(\mathrm{n}=3)$} & \\
\hline & & Mean & $\mathrm{CV}$ & Mean & $\mathrm{CV}$ & Mean & $\mathrm{CV}$ & \\
\hline \multicolumn{9}{|l|}{ SFA } \\
\hline Capric Acid & C 10:0 & 0.10 & 0.29 & 0.09 & 0.16 & 0.11 & 0.16 & ns \\
\hline Lauric Acid & $\mathrm{C} 12: 0$ & 0.56 & 0.40 & 0.41 & 0.02 & 0.35 & 0.34 & ns \\
\hline Myristic Acid & $\mathrm{C} 140$ & 3.93 & 0.30 & 3.21 & 0.03 & 3.31 & 0.06 & ns \\
\hline Pentadecanoic Acid & $\mathrm{C} 15: 0$ & 0.40 & 0.21 & 0.30 & 0.07 & 0.29 & 0.14 & ns \\
\hline Palmitic acid & $\mathrm{C} 16: 0$ & 17.68 & 0.05 & 18.61 & 0.15 & 20.85 & 0.18 & ns \\
\hline Heptadecanoic Acid & $\mathrm{C} 17: 0$ & 0.79 & 0.08 & 0.77 & 0.01 & 0.70 & 0.06 & ns \\
\hline Stearic Acid & $\mathrm{C} 18: 0$ & 13.59 & 0.10 & 14.71 & 0.07 & 13.66 & 0.15 & ns \\
\hline Arachidic Acid & $\mathrm{C} 20: 0$ & 0.11 & 0.20 & 0.11 & 0.20 & 0.09 & 0.00 & ns \\
\hline Heneicosanoic Acid & $\mathrm{C} 21: 0$ & $0.04^{\mathrm{a}}$ & 0.20 & $0.02^{\mathrm{b}}$ & 0.00 & $0.03^{\mathrm{b}}$ & 0.22 & * \\
\hline Bahenic Acid & $\mathrm{C} 22: 0$ & 0.05 & 0.29 & 0.04 & 0.35 & 0.06 & 0.33 & ns \\
\hline \multicolumn{9}{|l|}{ MUFA } \\
\hline Myristoleic Acid & $\mathrm{C} 14: 1$ & 0.14 & 0.28 & 0.12 & 0.35 & 0.11 & 0.10 & ns \\
\hline Palmitoleic Acid & $\mathrm{C} 16: 1$ & 1.77 & 0.06 & 1.99 & 0.27 & 1.90 & 0.08 & $\mathrm{~ns}$ \\
\hline Oleic Acid & $\mathrm{C} 18: \ln 9 \mathrm{c}$ & 24.45 & 0.10 & 28.50 & 0.15 & 27.71 & 0.22 & ns \\
\hline Cis-11-Eicosenoic Acid & $\mathrm{C} 20: 1$ & 0.05 & 0.28 & 0.05 & 0.16 & 0.05 & 0.29 & ns \\
\hline \multicolumn{9}{|l|}{ PUFA } \\
\hline Linoleic Acid & $\mathrm{C} 18: 2 \mathrm{n} 6 \mathrm{c}$ & 1.52 & 0.19 & 1.51 & 0.12 & 1.68 & 0.41 & ns \\
\hline Linolenic Acid & $\mathrm{C} 18: 3 \mathrm{n} 3$ & 0.19 & 0.65 & 0.22 & 0.10 & 0.24 & 0.21 & ns \\
\hline Cis-11,14-Eicosedienoic Acid & $\mathrm{C} 20: 2$ & 0.05 & 0.11 & 0.04 & - & 0.05 & 0.29 & ns \\
\hline $\begin{array}{l}\text { Cis-8,11,14-Eicosetrienoic } \\
\text { Acid }\end{array}$ & $\mathrm{C} 20: 3 \mathrm{n} 6$ & 0.05 & 0.42 & 0.06 & 0.13 & 0.06 & 0.37 & $\mathrm{~ns}$ \\
\hline Arachidonic Acid & $\mathrm{C} 20: 4 \mathrm{n} 6$ & 0.49 & 0.36 & 0.56 & 0.10 & 0.54 & 0.62 & $\mathrm{~ns}$ \\
\hline
\end{tabular}

SFA = Saturated Fatty Acid; MUFA = Mono Unsaturated Fatty Acid; PUFA = Poly Unsaturated Fatty Acid; $\mathrm{n}=$ samples size; Sig. $=$ significancy; $*=$ significant $(\mathrm{P}<0.05) ; \mathrm{ns}=$ non significantly $(\mathrm{P}>0.05)$

of fatty acids for energy utilization. Diversity of LPL gene SNP ss65478732 was associated with two poly unsaturated fatty acids i.e. dihomogamma-linolenic acid and arachidonic acid (Sevane et al., 2013)

Oleic was most abundant fatty acid in this study, followed by palmitic, stearic, myristic, palmitoleic and linoleic. Several studies have reported that oleic is the major fatty acid was found in sheep (Cloete et al., 2004; Costa et al., 2009; Gallardo et al., 2011; Borys et al., 2012;
Popova, 2014). Oleic acid is formed by stearic acid by activity of stearoyl CoA desaturase (Wood et al., 2008). Oleic play an important role in the enhancement of meat characteristics, cell elasticity, tenderness and palatability of meat (Smith et al., 2009). While Purbowati et al. (2005) was reported the most abundant fatty acids of local male sheep were linoleic, attended oleic, palmitic, stearic, linolenic and palmitoleic.

Guo et al. (2014) reported that on marbling fat quality in cattle and sheep was determined by 
polygenes and there expression influenced by environmental factors such as diseases and feed. According to Sondakh et al. (2012), feed has medium chain fatty acids $1.0-1.5 \%$ content could be increased unsaturated fatty acids (9.05\%$17.96 \%)$ and decreased saturated fatty acids $(6.59 \%-11.88 \%)$. The major genes which are potential include fatty acid binding protein 3 (FABP3), peroxisome proliferator activated receptor gamma (PPARG), diacyl glycerol oacyltransferase (DGAT1), acetyl CoA carboxylase alpha (ACACA), fatty acid synthase (FASN), fatty acid binding protein 4 (FABP4), carnitine palmitoyltransferase 1 binding (CPTIB), steoryl-CoA desaturase (SCD), peroxisome proliferator activated receptor gamma coactivated 1 alpha (PPARGC1A), activating transcription factor 4 (ATF4), SREB cleavage activating protein (SCAP) ( (Narukami et al. 2011; Sevane et al., 2013; Guo et al., 2014).

\section{CONCLUSION}

The results were presented 3 SNPs of LPL gene insertion g.26>C and g.27> G and a mutation c.192T $>\mathrm{C}$ on garut sheep and only one SNP insertion g.26>C/G on sumatera thin-tail ed sheep. Polymorphisms of LPL gene at base c. 192 on garut sheep was associated with saturated fatty acid heneicosanoic, whereas TT genotype $(0.04 \%)$ had higher percentage than CC $(0.03 \%)$ and CT $(0.02 \%)$. This designed primer has the potential as genetic marker of marbling quality of lamb garut sheep on marker assisted selection (MAS).

\section{REFERENCES}

AOAC (Association of Official Analytical Chemist). 2005. Official Methods of Analysis of the Association of Official Analitycal Chemist International. $18^{\text {th }}$ ed. Association of Official Analytical Chemists, Arlington.

Bonnet, M., C.Leroux, Y. Faulconnier, J-F Hocquette, F. Bocqueier, P. Martin and Y. Chilliard. 2000. A lipoprotein lipase activity and mRNA are up-regulated by refeeding in adipose tissue and cardiac muscle of sheep. Am. Soc. Nutr. Sci.:749-756

Borys, B., J. Oprzadek, A. Borys and M. Przegalinska-Goraczkowska. 2012. Lipid profile of intramuscular fat in lamb meat. Anim. Sci. Papers and Reports. 30(1):45-56.
Chizzolini, E., Zanardi, V. Dorigoni and S. Ghidini. 1999. Calorific value and cholesterol content of normal and low-fat meat and meat product. Food Sci. Technol. 10:119-128.

Cloete, J.J.E., L.C. Hoffman, S.W.P. Cloete and J.E. Fourie. 2004. A comparison between the body composition, carcass characteristics and retail cuts of south african mutton merino and dormer sheep. S. Afr. J. Anim. Sci. 34 (1):44-51

Costa, R.G., A.S.M. Batista, P.S. Azevedo, R.C.R.E. Queiroga, M.S. Madruga and J.T.A Filho. 2009. Lipid profile of lamb meat from different genotypes submitted to diets with different energy levels. R. Brass. Zootec. 38(3):532-538

Crisa, A., C. Marchitelli, L. Pariset, G. Gontarini, F. Signarelli, R. Napolitano, G. Catillo, A.Valentini and B. Moili. 2010. Exploring polymorphisms and effects of candidate genes on milk fat quality in dairy sheep. J. Dairy Sci. 93:3834-3845.

Ding, X.Z., C.N. Liang, X. Guo, C.F. Xing, P.J. Bao, M. Chu, J. Pei, X.S. Zhu and P. Yan. 2012. A novel single nucleotide polymorphism in exon 7 of LPL gene and its association with carcass traits and visceral fat deposition in yak (Bos grunniens) steers. Mol. Biol. Rep. 39:669-673

Dunner, S., N. Sevane, D. Garcia, O. Cortes, A. Valentini, J.L.Williams, B. Mangin, J. Canon, H. Leveziel, and T.G. Consortium. 2013. Association of genes involved in carcass and meat quality traits in 15 European bovine breeds. Livest. Sci. 154: 34-44

Gollardo MA, R Pulido, C Gallo. 2011. Fatty acid composition of longissimus dorsi muscle of suffolk down lambs fed on different dryland forages. Chileanjar 71(4):566-571.

Guo, B., K. Kongsuwan, P.L.G. Wood, G. Zhou, W. Zhang and B.P. Dalrympe. 2014. A gene expression estimator of intramuscular fat percentage for use in both cattle and sheep. J. Anim. Sci. Biotechnol. 5(35):1-12.

Hall, T. 2011. BioEdit; An important software for molecular biology. GERF Bull. Biosci. 2(1): 60-61.

Hocquette, J. F., G. Renand, H. Levéziel, B. Picard1, I.C. Malek. 2006. The potential benefits of genetics and genomics to improve beef quality - a review. Anim. Sci. Papers and Reports. 24 3):173-189 
Holmes, R.S., J.L. Vandeberg and L.A. Cox. 2011. Comparative studies of vertebrate lipoprotein lipase: a key enzyme of very low density lipoprotein metabolisms . Comp. Biochem. Physiol. Part D. Genomics Proteomics 6(2):224-234.

Karamichou, E., R.I. Richardson, G.R. Nute, K.P. Gibson and S.C. Bishop. 2006. Genetic analysis and quantitative trait loci detection, using a partial genome scan, for intramuscular fatty acid composition in Scottish Blackface sheep. J. Anim. Sci. 84:3228-3238.

Kumar,S., K. Tamura and M.Nei. 2004. MEGA3: Integrated software for molecular evolutionary genetic analysis and sequence alignment. J. Brief. Bioinform. 5(2):150163.

Lee, S.H. and K.L. Hossner. 2002. Coordinate regulation of ovine adipose tissue gene expression by propionate. J. Anim Sci 80: 2840-2849.

Mas'ud, M.S. 2012. Produksi, sifat fisik dan sifat kimia daging domba yang diberi ransum mengandung limbah udang. Dissertation. Bogor Agricultural UniversityBogor

Narukami, T., S. Sasazaki, K. Oyama, T. Nogi., M. Taniguchi and H. Mannen. 2011. Effect of DNA polymorphisms related to fatty acid composition in adipose tissue of Holstein cattle. J. Anim. Sci. 82:406-411

Nei, M. and S. Kumar. 2000. Molecular Evolution and Phylogenetics. Oxford University Press: New York.

Popova, T. 2014. Fatty acid composition of longissimus dorsi and semi membranosus muscles during storage in lambs reared in doors and on pasture. Emi.J.Food Agric. 26(3):302-308.

Purbowati, E., E. Baliarti, S.P.S. Budhi and W. Lestariana. 2005. Profil asam lemak daging domba lokal jantan yang dipelihara di pedesaan pada bobot potongan dan lokasi otot yang berbeda. Bull. Petern. 29(2):62-70
Ren, M.Q., J. Wegner, O. Bellmann, G.A. Brockmann, F. Scheider, F. Teuscher and K. Ender. 2002. Comparing mRNA levels of genes encoding leptin, leptin receptor and lipoprotein lipase between dairy and beef cattle. Dom. Anim. Endocrin. 23:371-381

Sambrook, J., E.F. Fritsch, and T. Maniatis. 1989. Molecular Clonning: A laboratory manual. $2^{\text {nd }}$ Ed. Cold Spring Harbor Laboratory Pr., USA.

Sevane N, E Armstrong, O Cortes, P Wienar, R Pong Wong, S Dunner and GQ Consortium. 2013. Association of bovine meat quality traits with gene included in the PPARG and PPARGC1A networks. Meat Sci. 94:328-335

Smith S., B. Gill, C.A. Lunt DK and Brooks, M.A. 2009. Regulation of fat and fatty acids composition in beef cattle. Asian-Aust. J. Anim. Sci. 22(9):1225-1233

Sondakh, E.H.B., L.M.Yusiati, H.Hartadi and E.Suryanto. 2012. The effect of methanogenic inhibitor feed on propionic acid and lamb meat chemical quality. J. Indonesian Trop. Anim. Agric. 37(3):183188

Wang, H and R.H.Eckel. 2009. Lipoprotein lipase: from gene to obesity. Am. J. Physiol. Endocrinol. Metab. 297:271-288

Williams, J.L. 2008. Genetic control of meat quality traits. In: Meat Biotechnology. (F.Toldra, ed.). Springer Sci., LLC.P. 21-60

Wong, D.W.S. 1989. Mechanism and Theory in Food Chemistry. An AVI Book. New York.

Wood, J.D., M. Enser, A.V. Fisher, G.R. Nute, P.R. Sheard, R.I. Richardson, S.I. Hughes and F.M. Whittingto. 2008. Fat deposition, fatty acid composition and meat quality: A review. Meat Sci. 78:343-358.

Yeh, F. C., R. C. Yang and T. Boyle. 1999. POPGENE Version 1.31: Microsoft Window-Based Freeware for Population Genetic Analysis. Canada University of Alberta (CAN). Edmonton, AB. 